\title{
Keeping Self-Interest under Control: Effects of Procedural Fairness and Project Success Rate in a Cost-Reduction Context*
}

\author{
ERTAMBANG NAHARTYO \\ Faculty of Economics and Business, \\ UNIVERSITAS GADJAH MADA
}

\author{
INTIYAS UTAMI \\ Faculty of Economics and Business, \\ SATYA WACANA CHRISTIAN UNIVERSITY
}

\begin{abstract}
In this study, we investigated the effects of procedural fairness (fair and no fair) and success rate on self-interest behavior. We compared a fair procedure condition that provides detail information regarding colleagues' cost structure and their willingness to sacrifice with an unfair condition without such information. Participants were assigned into two success rate groups: low and high. We expected that individuals who encountered a higher success rate condition were inclined toward a self-interest choice. Ultimately, we hypothesized that procedural fairness and success rate have an interaction effect on self-interest behavior. We conducted a controlled laboratory experiment to investigate individual decision process in a standard costing setting. The participants were 136 undergraduate business students enrolled in management accounting classes at three large private universities that acted to be the managers in a production department. They completed an experimental task on computer. The result of our experiment indicated a mitigating effect of procedural fairness on the individuals self-interest behavior once the individuals realized the pressure of cost reduction process. The findings allow concluding that both self-interest and social preferences are guiding motivational factors of individual behavior. The findings indicated that people are willing to pursue organizational goals on the expense of their personal benefits. The results also showed the process of encouraging employees to undertake projects that decrease their current benefit but potentially have future organizational payoff. However, we did not find the interaction effect between procedural fairness and success rate.
\end{abstract}

JEL Classificatoin: M41

Key Words: Self-interest; Procedural Fairness; Success Rate

\footnotetext{
"We thank the Faculty of Economics and Business Universitas Gadjah Mada for funding this project.

$\dagger$ Corresponding Author. Address Satya Wacana Christian University, J1. Diponegoro 52-60 Salatiga - Indonesia 50711. Telephone +6285226069200

E-mail intiyas@staff.uksw.edu
}

Received August 9, 2013; accepted April 9, 2014; available Online July 5, 2014 (Advance publication by J-STAGE) DOI: 10.11640/tjar.4.2014.02

Copyright(C2014 Research Institute for Economics \& Business Administration - Kobe University. 


\section{Introduction}

Firms that deal with intense competition must become excellent in developing low-cost, high-quality products that have value in the eyes of customers. Cost, quality, and value have been effective competitive weapons and managed throughout competing firms in the past three decades. Accordingly, the rapid progress of high technology and the increasingly competitive international markets have led to changes in management accounting practices in developed countries such as the United States and Japan (Atkinson et al. 2012; Monden and Monden 2007; Nishimura 2003).

Unfortunately, the wave of change does not seem to affect Indonesia's competitiveness positively. In fact, higher production costs driven by domestic cost inflation, which include higher labor costs, have weakened Indonesia's capability to compete internationally. According to the International Monetary Fund (IMF), Indonesia's unit labor cost has been steadily increasing, thus eroding the Nation's competitiveness (Thee 2006). Other studies report that in recent years, China, India, and Vietnam have emerged as strong competitors of Indonesia, since those countries export similar low-skilled workers and labor-intensive products (Waheeduzzaman 2011).

To gain competitive advantage, firms in Indonesia must ceaselessly research and develop low cost, yet high quality products that meet market's expectations. Firms have to give importance to how to reduce costs continuously. The yardstick of cost management should shift from how to meet standard costs to how to reduce costs continuously.

Cost reduction has been a fruitful area in management accounting research (Chenhall and Smith 2011; Lam 2011). Current studies have focused on factory cost measurement and control. Companies control costs in all value-adding stages, including the production phase (Endenich et al. 2011). Extant literature suggests that the cost reduction process requires cooperation between workers and managers (Nishimura 2003). To achieve continuous improvement in the production phase, companies emphasize the importance of organizing work that stimulates all employees' cooperation (Abrahamsson and Gerdin 2006). The working task of production employees has expanded to active engagement in reducing costs. Production employees should continually seek out and eliminate sources of process imperfection (Wynder 2008).

Hence, the effectiveness of the cost reduction process depends heavily on human factors. Wynder (2008) finds that efficient involvement of managers in cost-reduction efforts is achievable by employing activity-based costing information or by relying on the managers' intuitive understanding of the production process. Research shows that transforming shop-floor workers' responsibility from a vertically oriented perspective to a more horizontal can enhance employee cooperation for continuous improvement (Abrahamsson and Gerdin 2006). Lam (2011) finds that individuals are more likely to be involved in continuous improvement processes when they are evaluated over the long period.

Nevertheless, previous studies have provided incomplete answers about how individuals behave during the process of contributing within a production cost reduction context. Specifically, existing studies in the context base on behavioral assumptions that are subject to potential egocentric biases. Economic rationality is the main realm of behavioral decision research (Bazerman and Tenbrunsel 1998). A common assumption of classic economic models is that individuals would act opportunistically for private gain at the expense of the collective (Jensen and Meckling 1976). While this assumption is valid to explain behavioral tendency of people in certain conditions, it may 
only partially represent people behavior in various settings (Ghoshal 2005). This assumption is undermined by the actual decisions individuals make, which cannot be predicted by rational economic models. There is strong empirical evidence showing that individuals are subject to bounded rational behavior (Bigus 2012). Individuals, in fact, make decisions that are inconsistent with economic rationality (Rankin et al. 2008; Booker et al. 2007).

This study differs from prior research because it focuses on individuals' self-interest mitigation in a production cost reduction setting. This psychological focus aims at addressing an unanswered question of previous studies: whether individuals participating in a collective effort are able to control their self-interest leanings when they are exposed to social and psychological pressures. Specifically, this experimental study proposes that individuals face a conflict of interest when they see a possibility to realize personal gain from their participation in a standard costsetting process but their self-interest runs against the interests of the organization as a whole. We expect that participation in a process to determine production standard costs affect the extent to which individuals perceive this conflict of interest to constitute an ethical dilemma.

We address an important question related to a factor that can undermine individuals' selfinterest: how does perceived procedural fairness affect individuals' decisions? Previous studies found that people involved in participative decision-making are concerned with how fair the procedures are (Nahartyo 2013; Wan et al. 2012). Research indicates that managers often have stronger reactions toward the fairness of the procedures than toward distributive fairness (Luo 2007; Konovsky 2000). While studies reporting reactions to fair procedures have shown solid results, there is not conclusive evidence yet regarding whether procedural fairness affects individuals' decisions in setting standard costs. Specifically, the study examines the role of procedural fairness, particularly the "soft side" (i.e., group value) of procedural justice elements, in explaining how individuals take into account fair conditions in making standard cost decisions.

The study also focuses on the effect of uncertainty or ambiguity on individuals' resource allocation decisions. Previous research shows that individuals' perception of the risks involved (i.e., level of uncertainty and/or ambiguity) influence their choice of options. This perception alters their self-interest behavior. We hypothesize that the level of success rate is of importance in determining standard cost decisions. Psychological theory, particularly expectancy theory, suggests that people are willing to postpone short-term benefits when there is an acceptable likelihood of future payoff (Fudge and Schlacter 1999). Therefore, related to the first question above, we address the literature gap formulating the second question: are the effects of procedural fairness different depending on the success rate? Based on the framework, we expect that there is a negative relation between the success rate and individuals' willingness to delay short-term gain.

This study contributes to behavioral management accounting literature in two ways. First, it considers the impact of social preferences as well as personal perception on resource allocation decisions. The findings will allow concluding that both self-interest and social preferences are guiding motivational factors of individual behavior. Such explanation, to answer why people must pursue organizational goals at the expense of their personal benefit, are relevant to the broader topics of self-control and organizational commitment, and has implications for settings such as the workplace. Secondly, this research sheds light on the process of how to encourage employees to undertake risky projects that decrease current financial benefit but potentially have future organizational advantages.

We tested our hypotheses by conducting a laboratory experiment in which 136 undergraduate business students, each one acting as a member of management of a production 
department. All subjects were to make decisions regarding product standard costs. We posit that when subjects have the opportunity to participate in a standard costing process, they have incentives to alter the decision to acquire a greater share of resources. We manipulated both procedural fairness and success rates between subjects at two levels. In the fair condition, subjects received information regarding the willingness of their colleagues to reduce their share of resources (wages) and to disclose their cost structure, whereas in the non-fair condition subjects did not receive such information. In the low (high) risk project condition, subjects were informed that the success rate estimate of the project is 80 percent (between $20-40$ percent).

\section{Background and Hypotheses}

\subsection{Setting}

We set up a setting in which individuals work in a production department and ther duty is to determine the standard cost of a particular product. The standard cost consists of three elements: material, labor, and overhead cost. The individual realizes the benefit of keeping the labor cost at the maximum amount and that reducing the material cost will lead to product quality deterioration. The overhead cost was fixed and could not be altered. Further, each individual was endowed with a certain amount of money to be allocated to material, labor, or overhead costs. However, utility could be derived only from the labor cost. In this setting, each individual has to decide on the amount of money to allocate among the three product cost elements. The extent to which the individual allocated money to labor costs represents self-interest decision.

This raises a question regarding the method or scheme organizations should employ to motivate individual employees to allocate resources as a manner to provide a benefit as great as possible for the organizations. In this study, we examined the efficacy of procedural fairness and success rate to alter allocation decisions. We selected the variables described below for their theoretical importance and their common use in practice and research (Nahartyo 2013; Loi et al. 2012; Lam 2011; Fudge and Schlacter 1999). For example, Nahartyo (2013) discusses two components of procedural justice theory: self-interest theory and group value model. Loi et al. (2012) provide an explanation of why fair procedures influence employees' feeling of uncertainty. Lam (2011) documents the effect of a longer evaluation window on the effectiveness of encouraging employees to focus on long-term rather than short-term profitability. Fudge and Schlacter (1999) offers a model based on expectancy theory to eliminate unethical practices of employees that may harm the long-term interests of the company.

\subsection{Mitigating effect of procedural fairness}

The question of what motivates individual behavior in social interactions is central for a better understanding of participative decision-making. Whether individuals selfishly maximize their own material welfare or whether they take the well-being of others into account is debatable. Traditional rational choice theory suggests that individuals are both self-interested and inequality averse (Jensen and Meckling 1976). Prior research suggests that managers, under certain conditions, exhibit myopic behavior. That means that they choose actions that improve shortterm profitability at the expense of long-term profitability (Bhojraj and Libby 2005). On the other hand, opponents of the theory have developed arguments that explain that even in genuine distributional problems, individuals still hold sufficiently strong social preferences (Sauermann and Kaiser 2010; Davis et al. 1997). 
Procedural fairness represents the degree to which the processes used to make a decision are fair (Konovsky 2000). In this study, we define procedural justice as the extent to which employees judge the fairness of the standard costing process. Procedural fairness provides valuable information to the sense-making processes through which individuals develop their attitudinal and behavioral reactions to valued outcomes they receive from organizations (Brockner 2002). Self-interest theory of procedural justice (Thibaut and Walker 1975) asserts that procedures are considered as fair if those affected by the outcome of the procedures have control over the decision process. The theory suggests that in a fair situation, people may forego short-term benefits from a relationship and focus on forthcoming advantageous outcomes in the future. On the other side, if the procedure is perceived as unfair, people will believe that the future outcome is negative and they will care mostly about short-term outcomes.

Lind and Tyler (1988) provide an explanation beyond self-interest theory. Their group value model postulates that in addition to economic benefits, individuals value psychological rewards in an economic relationship. People are predisposed to belong to social groups and they are very attentive to signs and symbols that communicate information about their position within groups. The group value model suggests that people are concerned about their long-term social relationships and do not view them as a one-time deal (Tyler 1994). This leads people to be concerned with three factors: neutrality of the decision-making procedure, trust in the groups, and evidence about social standing or status. If neutrality exists, then the decision-maker is free from bias. People perceive decision-makers as neutral if they create a level playing field for all. Trust refers to the degree to which people believe that the decision-maker intends to act in a fair manner. Standing is the position that individuals possess in a group as the result of how the group treats them. Being treated with respect and dignity implies that a person is a valued member of the organization and furnishes a source of self-validation.

The current study measures the extent to which individuals make egocentric decisions and how procedural fairness mitigates the individuals' inclination to act selfishly. The presence of high procedural fairness prevents individuals from developing feelings of animosity toward the organization and makes them more likely to accept and support the organization and its decisions (Brockner, 2002). Specifically, high procedural justice stimulates trust in the organization. Applied to the current study, this sense-making perspective simply sees that procedural fairness will also attenuate the individuals' myopic behavior tendency.

In addition, uncertainty management theory relates fairness with uncertainty in the sense that individuals tend to rely heavily on fairness information when they are confronted with uncertainty (Loi et al. 2012). According to this theory, people tend to focus on environmental signals to reduce uncertainties and procedural fairness information is one of the most important cues. We thus anticipate that with higher levels of procedural fairness individuals are willing to postpone their short-term, individual benefit in exchange for an enhanced long-term relationship with the organization. Acting as a management team member in the standard costing process, individuals are expected to undergo an ethical dilemma when a cost reduction program is enacted. The study expects a mitigating effect of procedural fairness on the individuals' self-interest behavior once the individuals realize that the standard costing process produces cost reduction pressure. The following hypothesis is thus proposed.

H1: Subjects in fair procedure condition will allocate less money to labor cost. 


\subsection{The effect of project success rate}

The project success rate explains the project risk in gaining domain. Project risk is explained with uncertainty and ambiguity. The Merriam-Webster Dictionary defines uncertainty as a doubt or lack of sureness about someone or something. Uncertainty may range from a falling short of certainty to an almost complete lack of conviction or knowledge especially about an outcome or result. In the literature, uncertainty is subject-specific, that is, uncertainty resides in the eye of the beholder (Geersbro and Ritter 2010). Different individuals may have varying degrees of perceived uncertainty in a similar situation.

According to the Merriam-Webster Dictionary, ambiguity is something that does not have a single clear meaning: something that is ambiguous. Ambiguity can represent a situation in which something can be understood in more than one way and it is not clear which meaning is intended. There is a controversy in understanding the concepts of uncertainty and ambiguity. Geersbro and Ritter (2010) argue that ambiguity is not the same as uncertainty. They contend that the lack of information causes uncertainty, while the quality of information is the source of ambiguity. On the other hand, a number of academics have defined ambiguity very closely to the definition of uncertainty. Bigus (2012) states that ambiguity implies uncertainty about the probability that a future event will occur. This view of ambiguity focuses on the amount of information available, which fits better with the definition of uncertainty. Ho et al. (2002) conceive ambiguity as adding a second order probability distribution on top of the probabilistic uncertainty in making a decision under risk. Stated differently, in an ambiguous situation, people may reason in a way analogous to how they face uncertainty. Our study adopts the latter argument and defines project success rate as the accumulation of uncertainty and ambiguity effects in carrying out a specific process, that is, a cost reduction project.

Chang et al. (2002) propose a framework for resource allocation projects. Chang et al. assert that project-related factors (e.g., uncertainty), decision-makers' characteristics (e.g., knowledge and experience), and the managerial environment (e.g., information asymmetry) affect managers' resource allocation decisions. The framework proposes that in making decisions regarding resource allocation among different projects, future uncertainty affects the managers' subjectivity. The link between uncertainty and individuals' subjectivity in making decisions is critical in assessing the characteristics and effectiveness of resource allocation.

Ho et al. (2002) state that the outcome and ambiguity of payoffs probability affects managerial decisions involving allocation of resources. They found that when managers face imprecise probabilities, their perceptions of the risks involved influence their choice of options. Specifically, managers tend to choose the least ambiguous option. Tversky and Kahneman (1981) showed that the prospect theory model could describe a value function over outcomes. The model implies that people tend to be averse to risk when they might have something to gain and to be risk prone when they might have something to lose. In relation with ambiguity, the model indicates that ambiguity may affect such probabilistic decision weights. This is also suggested by research findings that show how people generally avoid ambiguity in the gains domain and are ambiguity prone in the loss domain (Cabantous 2007).

Ambiguity aversion may have an important implication: pessimism. Pessimism means that individuals overestimate the probability of the worst outcome. With ambiguity aversion, people tend to weigh less favorable outcomes more highly, and are, therefore, more pessimistic. For instance, other things being equal, individuals usually prefer a 30 percent chance to a (imprecisely defined) chance of 10-50 percent (Bigus 2012). In short, individuals prefer a certain probability 
to a probability range. This implies that ambiguity aversion can be considered rational. Based on our arguments, we expect that individuals with a higher success rate (80 percent) will exhibit more self-interest choice than those with a lower success rate (20-40 percent). Thus, the following hypothesis is proposed.

H2: Subjects in a high success rate condition will allocate more money to labor costs.

\subsection{The interaction effect of procedural fairness and success rate}

The procedural fairness theory suggests that people are attentive to long-term social relationships and expect valuable outcomes from those relationships. When they perceive procedural fairness, individuals may delay short-term advantages in exchange to a long-term gain. Moreover, when individuals deal with an uncertain decision environment, they depend on information about procedural fairness to reduce the uncertainty level in coming to a decision. In organizational settings, the perception of being fairly treated leads to a variety of pro-social consequences, such as higher commitment to organizations and institutions, more extrarole citizenship behavior, greater likelihood of conflict prevention and resolution (Van den Bos and Lind 2004). As discussed in the previous section, we expect that procedural fairness perception will lead to individuals' lower inclination to self-interest decisions.

Expectancy theory asserts that motivation is a function of individuals' perceptions of their environment (Fudge and Schlacter 1999). Of particularly important in this study are three factors of the theory: effort-performance expectancy, performance-outcome expectancy, and valence. The first factor relates to the individual's perception that effort is positively correlated with the level of performance. The second corresponds to a person's expectations that the rewards that will be received are closely tied to the level of performance. Valence is associated with the degree to which an individual values a particular reward. The more a person values the reward received for the effort, the more motivated that person will be to receive the reward. Rewards for which people generally have a high valence include salaries, bonuses, promotions, and recognition. Hence, in the present study, we expect that high certainty or low ambiguity (i.e., low success rate) will encourage individuals to pursue a project that decreases current benefit but potentially have positive future payoffs.

Existing literature on motivation reveals that the pursuit of personally constructed goals involves maintenance of a positive self-regard, whereas striving for socially constructed goals involves identification with the role obligations at work (Chen et al. 2009). Personal goals may not have high social value and are not necessarily subject to consistent expectations from others. On the contrary, social goals are generally associated with expectations from others and have high social value. Hence, we infer that the consideration of social preferences considerably adds explanatory power to rational predictions of behavior in standard costing decisions. Both selfinterest and social obligation motivate individual behavior in decision-making.

Taken together, the theories discussed above imply that individuals who perceive fair procedural conditions and are exposed to a high likelihood of future advantage will be more likely to behave in a less self-interest manner. Then, we propose the following hypothesis.

H3: Higher procedural fairness perception and lower success rate will lead to less money allocated to labor cost. 


\section{Method}

Laboratory experiments provide an excellent method to investigate individual decision process in standard costing. Due to real-world complexity, an empirical test with field data bears the major problem that it is hardly possible to control for all possible causal influences.

\subsection{Participants and design}

The participants were 136 undergraduate business students at three large private universities in Java, Indonesia. They were from Sanata Dharma University (33 students), Satya Wacana Christian University (36 students), and STIE YKPN (67 students). We conducted the experiment from June $20^{\text {th }}$ to $26^{\text {th }}$, 2013. We asked for participation via email and print media. Participants were randomly assigned to one of four between-subjects treatment conditions. We obtained the four between-subjects treatment conditions by fully crossing two group procedural fairness conditions with two group success rates. First, we assigned the participants to one of two procedural fairness conditions (fair and unfair conditions). Second, we assigned the participants to one of two group success rates (low and high success rates) in gaining domain. Finally, participants in all four between-subjects conditions completed an experimental task and the entire experiment via computer. Figure 1 below shows the entire cells.

\subsection{Procedure}

The experimental procedure comprised six steps:

1. We set up the computer lab with predesigned software and when participants arrived, we randomly assigned them to computer terminals.

2. The first few computer screens explained participants' role and task. Each participant acted as a manager in the production department of a medium size furniture factory. Their task was to determine a standard cost in the department. The software was designed to be attractive and informative enough to assist the role and task internalization. A number of questions were asked to ensure that the participants understood their role and task and its requirements.

3. We informed the participants that they would earn "dollars" during the experimental task and that each dollar would be converted into raffle tickets at the rate of one ticket per dollar. At the conclusion of the experiment, the participants received their tickets. The tickets were drawn to select four winners. Each winner received 500 thousand rupiahs.

4. The next computer screens described the experimental task. Participants completed an experimental task that consisted of two stages. At the first stage, participants had to determine a standard cost for a particular product. Weinformed the participants that they could allocate 2,400 dollars to three costcomponents: materials, labor, and overhead. There were three choices of materialsand costs: high quality material with the highest cost (900-1,000 dollars), moderate quality material with a modest cost (700-899 dollars), and low quality material with the lowest cost (300-699 dollars). The maximum amount of labor cost was set at 1,000 dollars. Participants learned they would receive the entire labor costs that they decided during the experiments as their payment. The overhead cost was set fixed at the amount of 500 dollars. Participants were not allowed to change the overhead 
cost. In this stage, participants had to make their first decision regarding how to allocate the $\$ 2,400$ standard costs to labor costs and material costs.

5. At the second stage, we informed participants that due to market changes, the company should reduce its production cost to 2,000 dollars. The participants should decide whether they would reduce the material cost, labor cost, or both. In the fair procedure condition, we told the participants that their colleagues (other managers) were willing to reduce labor cost at minimum level and to maintain the quality of material at the maximum level. In the unfair procedure condition, we told the participants that the other managers would reduce the production cost but without the detail of the cost reduction. In the low-risk project condition, we informed the participants that the probability of success of the cost reduction project was 80 percent. In the high-risk project condition, we told the participants that the probability of success was between 20 to 40 percent. They received manipulation checks throughout the treatment processes. During this second stage, participants had to make their second decision regarding how to allocate the $\$ 2,000$ standard cost to labor cost and material cost. They made the decision after receiving information about fair/unfair procedure and high-risk/low-risk project condition.

6. Next, the participants were to determine the money allocation to the cost elements. Upon completing the task, participants answered an exit-questionnaire. Lastly, we calculated participant's payments (in form of raffle tickets to be drawn). We announced the participants who won the prizes soon after all experimental sessions finished.

\subsection{Measures}

We examined resource allocation for our dependent variable and fairness (fair and unfair conditions) and success rate (high and low) for our independent variables. Low success rate was 20-40 percent and high success rate was 80 percent.

\section{Results}

The test indicated significant difference across the allocation resources between group and within group for any following variables: age, GPA, gender, and grade. A one-way ANOVA was employed to test homogeneity of the experiment cell and demographic characteristics (table 1).

We also tested the disturbance factor that might influence the labor cost allocation decision, that is, the level of understanding of cost accounting. We tested with seven questions about cost accounting and the score of each question was 20. The ANCOVA analysis with independent variable fairness and success rate, and covariate score of understanding of cost accounting is presented in table 2. The ANCOVA test indicated that the score of understanding of cost accounting was 0.730 . It means that there was no influence level of understanding of cost accounting in decision of labor cost.

\subsection{Hypotheses test: Mitigating effect of procedural fairness}

Hypothesis 1 states that subjects in fair procedures condition will allocate less money to labor costs. An independent t-test compared the participants' decision with fair procedure and 
participants' decision with unfair procedures. The results are reported in table 3.

The independent t-test indicated that labor costs that determined participants in the fair group were 598.51 and labor costs that were determined by participants in the unfair group were 681.16. There was significant difference $(\mathrm{p}=0.001)$, thus hypotheses 1 was supported. Subjects that received information preference from other production managers that chose high material quality would determine labor cost lower than subjects that received no information from other production managers. That information indicates that fairness has a significant role on mitigating manager self-interest. This result supported the traditional rational choice theory that individual tends to prioritize self-interest and expect the highest incentive (Jensen and Meckling, 1976). An individual will get the benefit for himself in the short time (Bhojraj and Libby 2005) and ignores the organization's long-term goals.

Fairness procedural treatment was information that another manager chose the best material quality and this situation encouraged participants to develop attitudinal reaction and behavior on the value of the organization (Brocker 2002). This result supported Konovsky's (2000) argument according to which procedural fairness indicates that the decision-making process is fair. The result was also similar to a study by Thibaut and Walker (1975) that fair procedure was an influenced outcome of the procedure that controlled the decision-making process and ignored the short-term interest and focused on interest forward. When an unfair procedure is perceived, individuals will believe that forward outcome is negative and will focus on the short-time outcome.

\subsection{The effect of project success rate}

Hypothesis 2 predicts that subjects in a high success rate condition allocate more money to labor costs. Table 4 presents the results of the independent t-test.

Table 3 presents the results of the independent $t$-test showing that the mean of labor costs for high success rate was 669.12 and the mean of labor costs for low success rate was 611.76. The difference between the two groups was statistically significant $(\mathrm{p}=0.028)$ and hypothesis 2 was supported. This result coincides with the prospect theory of Tversky and Kahneman (1981), which states that individuals will tend to avoid risk if there is in gain domain and will take a risk if there is in loss domain. This research used success rate (high and low) in gaining domain. High rate shows that the rate of project success was 80 percent and low rate shows that it was 20-40 percent.

This study indicated that managerial decisions to allocate production costs to labor costs and material costs with a fixed overhead cost were influenced by the outcomes and ambiguity of incentives that were received. This result confirms the view of Ho, Keller, and Keltyka (2002). Participants who acted as managers had the choice of taking high incentives but sacrificing high quality and ambiguity to make decisions. This result also supports Cabantus' (2007) view according to which individuals generally avoid ambiguity in the gaining domain and feel ambiguity in the loss domain.

\subsection{The interaction effect of procedural fairness and project success rate}

Hypotheses 3 states that higher procedural fairness perception and lower success rate would lead to less money allocated to labor costs. Table 5 shows the interaction test with a two-way ANOVA. The probability value of fairness was 0.001 and risk was 
0.018 , but the interaction was not statistically significant $(\mathrm{p}=0.192)$. The results indicate that there was no interaction effect between procedural fairness and success rate.

This finding did not support the fairness procedural theory, when individual decisions depend on the success rate, even though the partial test showed that fairness and success rate influenced decision-making. Individual decision-making was more attentive to long-term social relationships and the expectation to get outcome did not influence the success rate.

\section{Conclusion}

This study provides empirical evidence that procedural fairness influenced participant decision making, so in fairness condition participants focus on high material quality compared with incentive that was determined from labor costs. This research also supports that in higher success rate, the decision making to allocate labor costs tends to prioritize self-interest by allocating high labor costs. However, it does not support the interaction effect of procedural fairness and success rate. Future research could provide additional effect on issues examine in this paper. First, we made a specific choice for success rate (low and high) for the gaining domain (success rate); future research could examine the sensitivity of our results with affective response like Moreno et al. (2002). The affective response measures how individuals feel conflict when choose labor costs that impact in their incentive or high material quality. Second, future research can expand success rate in the gaining and loss domains. Third, future research could examine two employee groups and use single decisions that impact in incentive group and will confirm Fisher, Peffer and Sprinkle's (2005) point. They argue that employee shirking could increase within larger groups. This study used the economic incentive to stimulate individuals' self-interest. Nevertheless, the form of the economic incentive may introduce a possible hypothetical bias that is usually doubted in questionnaire survey, because the possibility of being a winner in our experiment (i.e., $4 / 136=0.029)$ was too low. 


\section{REFERENCES}

ABRAHAMSSON, G., AND J. GERDIN. 2006. Exploiting institutional contradictions the role of management accounting in continuous improvement implementation. Qualitative Research in Accounting and Management 3 (2): 126-144.

Atkinson, A. A., R. S. Kaplan, E. M. Matsumura, And S. M. Young. 2012. Management Accounting. Ed. 5. Pearson: Upper Saddle River, N.J.

BAZERMAN, M.H., AND A. TEnBRUNSEL. 1998. The role of social context on decisions: Integrating social cognition and behavioral decision research. Basic and Applied Social Psychology 20 (1): 87-91.

BHOJRAJ, S. AND R. LIBBY. 2005. Capital market pressure, disclosure frequency-induced earnings/cash flow conflict, and managerial myopia. The Accounting Review 80 (1): 1-20.

BIGUS, J. 2012. Vague auditing standards and ambiguity aversion. Auditing: A Journal of Practice and Theory 31 (3): 23-45.

Booker, D. M., A. R. Drake, And D. L. Heitger. 2007. New product development: How cost information precision affects designer focus and behavior in a multiple objective setting. Behavioral Research in Accounting 19 (1): 19-41.

BRocKNER, J. 2002. Making sense of procedural fairness: How high procedural fairness can reduce or heighten the influence of outcome favorability. Academy of Management Review 27 (1): 58-76.

BurnetT, M. F., I. O. Williamson, AND K. M. BARTOL. 2009. The moderating effect of personality on employees' reactions to procedural fairness and outcome favorability. Journal of Business and Psychology 24 (4): 469-484.

CARR, J. C., B. T. GREgory, AND S. G. HARRIS. 2010. Work status congruence's relation to employee attitudes and behaviors: The moderating role of procedural justice. Journal of Business and Psychology 25 (4): 583-592.

CABAnTOUS, L. 2007. Ambiguity aversion in the field of insurance: Insurers' attitude to imprecise and conflicting probability estimates. Theory and Decision 62 (3): 219-240.

ChAng, C. J., J. L. Y. Ho, AND P. LIN. 2002. Managers' resource allocation: Review and implications for future research. Journal of Accounting Literature 21: 1-37.

Chen, S. W., H. H. Wang, C. F. Wei, B. J. FwU, And K. K. HwanG. 2009. Taiwanese students' selfattributions for two types of achievement goals. The Journal of Social Psychology 149 (2): 179-194.

Chenhall, R. H. AND D. SMITH. 2011. A review of Australian management accounting research: 19802009." Accounting and Finance 51 (1): 173-206.

Davis, J. H., F. D. Schoorman, And L. Donaldson. 1997. Toward a stewardship theory of management. Academy of Management Review 22 (1): 20-47.

Endenich, C., M. BrandaU, And A. Hoffjan. 2011. Two decades of research on comparative management accounting - achievements and future directions. Australian Accounting Review 21 (4): 365-382.

Fisher, J. G., L. A. MAInes, S.E. PEFFER, AND G. B. SPRINKLE. 2005. An experimental investigation of employer discretion in employee performance evaluation and compensation. The Accounting Review 80 (2): 563-583

GEERSBRO, J. AND T. RITTER. 2010. External performance barriers in business networks: Uncertainty, ambiguity, and conflict. Journal of Business and Industrial Marketing 25 (3): 196-201. 
GHoshaL, S. 2005. Bad management theories are destroying good management practices. Academy of Management Learning and Education 4 (1): 75-91.

HARTMANn, F. G. H. AND V. S. MAAS. 2010. Why business unit controllers create budget slack: Involvement in management, social pressure, and machiavellianism. Behavioral Research in Accounting 22 (2): 27-49.

Ho, J. L. Y., L. R. KELLER, AND P. KELTYKA. 2002. Effects of outcome and probabilistic ambiguity on managerial choices. Journal of Risk and Uncertainty 24 (1): 47-74.

Jensen, M. And W. MecKling. 1976. Theory of the firm: Managerial behavior, agency costs and ownership structure. Journal of Financial Economics 3 (4): 305-360.

KOnOVsKY, M. A. 2000. Understanding procedural justice and its impact on business organizations. Journal of Management 26 (3): 489-511.

LAM, M. 2011. The joint effect of performance evaluation windows and project risk on continuous improvement initiatives: Evidence from the balanced scorecard. Journal of Organizational Culture, Communications and Conflict 15 (1): 131-145.

LIND, E. A., AND T. R. TYLER.1988. The Social Psychology of Procedural Justice. Plenum: New York.

LOI, R., L. W. LAM, AND K. W. CHAN. 2012. Coping with job insecurity: The role of procedural justice, ethical leadership and power distance orientation. Journal of Business Ethics 108 (3): 361-372.

LUO, Y. 2007. The independent and interactive roles of procedural, distributive, and interactional justice in strategic alliances. Academy of Management Journal 50 (3): 644-664.

Moreno, K., T. KIDA, J. F. SMITH. 2002. The impact of affective reactions on risky decision making in accounting contexts. Journal of Accounting Research 40 (5): 1331-1349.

Monden, Y. AND Y. Monden. 2007. How Japanese legal and accounting rules can facilitate business group restructuring. Monden, Y., M. Kosuga, Y. Nagasaka, S. Hiraoka and N. Hoshi eds. Japanese Management Accounting Today. World Scientific Publishing Co: Singapore.

NAHARTYO, E. 2013. Budgetary participation and procedural justice: Evidence from stretch budget condition. Global Journal of Business Research 7 (4): 85-100.

NishimurA, A. 2003. Management Accounting: Feed Forward and Asian Perspectives. Palgrave Macmillan: New York.

RANKIn, F. W., S. T. SCHWARTZ, AND R. A. YOUNG. 2008. The effect of honesty and superior authority on budget proposals. The Accounting Review 83 (4): 1083-1099.

SAUERMAnN, J. AND A. KAISER. 2010. Taking others into account: Self-interest and fairness in majority decision making. American Journal of Political Science 54 (3): 667-685.

SCHLACTER, J. L. AND R. S. FudGE. 1999. Motivating employees to act ethically: An expectancy theory approach. Journal of Business Ethics 18 (3): 295-304.

THEE, K. W. 2006. Policies affecting Indonesia's industrial technology development. ASEAN Economic Bulletin 23 (3): 341-359.

Thibaut, J. And L. Walker. 1975. Procedural Justice A Psychological Analysis. Lawrence Erlbaum Associates: Hillsdale, N.J.

Tyler, T. 1994. Psychological models of the justice motive: Antecedents of distributive and procedural justice. Journal of Personality and Social Psychology 67 (5): 850-863.

TVersky, A. And D. Kahneman. 1981. The framing of decisions and the psychology of choice. Science 211 (4481): 453-458. 
VAN DEN BOS, K. AND E. A. LIND. 2004. Fairness heuristic theory is an empirical framework: A reply to Árnadóttir. Scandinavian Journal of Psychology 45 (3): 265-268.

Waheeduzzaman, A. N. M. 2011. Competitiveness and convergence in G7 and emerging markets. Competitiveness Review: An International Business Journal 21 (2): 110-128.

Wan, H. L., M. Sulaiman, And A. Omar. 2012. Procedural justice in promotion decisions of managerial staff in Malaysia. Asia Pacific Business Review 18 (1): 99-121.

WYNDER, M. 2008. Employee participation in continuous improvement programs: The interaction effects of accounting information and control. Australian Journal of Management 33 (2): 355-374. 


\section{APPENDIX}

FIGURE 1. EXPERIMENTAL DESIGN

\begin{tabular}{|c|c|c|c|c|c|c|c|}
\hline & & \multirow{4}{*}{$\begin{array}{l}\text { Low } \\
\text { High }\end{array}$} & \multicolumn{5}{|c|}{ Procedural Fairness Conditions } \\
\hline \multirow{3}{*}{\multicolumn{2}{|c|}{ Project success rate }} & & \multicolumn{3}{|c|}{ Fair } & \multicolumn{2}{|c|}{ Unfair } \\
\hline & & & \multicolumn{2}{|l|}{ Cell 1} & & \multicolumn{2}{|c|}{ Cell 2} \\
\hline & & & \multicolumn{2}{|l|}{ Cell 3} & \multicolumn{2}{|c|}{ Cell 4} & \\
\hline \multicolumn{8}{|c|}{$\begin{array}{l}\text { Note: Cell1: Fair condition, low risk } \\
\text { Cell 2: Unfair condition, low risk } \\
\text { Cell 3: Fair condition, high risk } \\
\text { Cell 4: Unfair condition, high risk }\end{array}$} \\
\hline \multicolumn{8}{|c|}{ TABLE 1. HOMOGENEITY TEST } \\
\hline & & & $\begin{array}{l}\text { Sum of } \\
\text { Squares }\end{array}$ & Df & $\begin{array}{l}\text { Mean } \\
\text { Square }\end{array}$ & $\mathrm{F}$ & Sig \\
\hline \multirow[t]{3}{*}{ Gender } & \multicolumn{2}{|c|}{ Between Groups } & 2.398 & 9 & 0.266 & 1.227 & 0.284 \\
\hline & \multicolumn{2}{|c|}{ Within Groups } & 27.366 & 126 & \multirow{2}{*}{0.217} & & \\
\hline & Total & & 29.765 & 135 & & & \\
\hline \multirow[t]{3}{*}{ Age } & \multicolumn{2}{|c|}{ Between Groups } & 2.404 & 9 & 0.267 & 0.774 & 0.640 \\
\hline & \multicolumn{2}{|c|}{ Within Groups } & 43.478 & 126 & \multirow{2}{*}{0.345} & & \\
\hline & Total & & 45.882 & 135 & & & \\
\hline \multirow[t]{3}{*}{ GPA } & \multicolumn{2}{|c|}{ Between Groups } & 3.145 & 9 & 0.349 & 0.766 & 0.648 \\
\hline & \multicolumn{2}{|c|}{ Within Groups } & 57.495 & 126 & \multirow{2}{*}{0.456} & & \\
\hline & Total & & 60.640 & 135 & & & \\
\hline \multirow[t]{3}{*}{ Grade } & \multicolumn{2}{|c|}{ Between Groups } & 15.243 & 9 & 1.694 & 0.736 & 0.675 \\
\hline & \multicolumn{2}{|c|}{ Within Groups } & 289.786 & 126 & 2.300 & & \\
\hline & \multicolumn{2}{|l|}{ Total } & 305.029 & 135 & & & \\
\hline
\end{tabular}


TABLE 2. RESULT OF ANCOVA

\begin{tabular}{lrrrrr}
\hline \hline Independent Variable & $\begin{array}{c}\text { Type III Sum } \\
\text { of Squares }\end{array}$ & Df & Mean Square & F & Sig. \\
\hline Fairness & $236,780.413$ & 1 & $236,780.413$ & 11.316 & 0.001 \\
Success rate & $115,219.762$ & 1 & $115,219.762$ & 5.507 & 0.020 \\
$\begin{array}{l}\text { Score of } \\
\text { understanding cost } \\
\text { accounting }\end{array}$ & $2,502.539$ & 1 & $2,502.539$ & 0.120 & 0.730 \\
\hline
\end{tabular}

TABLE 3. HYPOTHESIS 1 TEST

\begin{tabular}{|c|c|c|c|c|c|}
\hline & & $\mathrm{N}$ & Mean & SD & Independent $\mathrm{t}$-test \\
\hline \multirow{3}{*}{$\begin{array}{l}\text { Procedural } \\
\text { Fairness }\end{array}$} & Fair & 67 & 598.51 & 153.24 & $\mathrm{~F}=0.02$ \\
\hline & & & & & $\mathrm{p}=0.965$ \\
\hline & Unfair & 69 & 681.16 & 141.71 & $\begin{array}{r}t=-3.267 \\
p=0.001\end{array}$ \\
\hline
\end{tabular}

TABle 4. Test OF Hypotheses 2

\begin{tabular}{|c|c|c|c|c|c|}
\hline & & $\mathrm{N}$ & Mean & SD & Independent $t$-test \\
\hline \multirow{2}{*}{$\begin{array}{l}\text { Project success } \\
\text { rate }\end{array}$} & High & 68 & 669.12 & 167.74 & $\begin{array}{l}F=4.544 \\
p=0.035\end{array}$ \\
\hline & Low & 68 & 611.76 & 131.05 & $\begin{array}{l}\mathrm{t}=2.222 \\
\mathrm{p}=0.028\end{array}$ \\
\hline
\end{tabular}

TABLE 5. INTERACTION EFFECT TEST

\begin{tabular}{llllll}
\hline \hline Effect & DF & Type III SS & $\begin{array}{l}\text { Mean } \\
\text { Square }\end{array}$ & F-Value & P > F \\
\hline Fairness & 1 & $247,352.941$ & $247,352.941$ & 11.965 & $0.001^{*}$ \\
Risk & 1 & $117,647.059$ & $117,647.059$ & 5.691 & $0.018^{* *}$ \\
$\begin{array}{l}\text { Fairness * } \\
\text { Risk }\end{array}$ & 1 & $35,588.235$ & & & 0.192 \\
Error & 132 & $2,728,823.529$ & \\
\hline \multicolumn{5}{c}{$\begin{array}{l}\text { Note: }{ }^{*} \text { significance at } 1 \% \\
\text { *significance at 5\% }\end{array}$} \\
\end{tabular}




\section{Experimental Test Instruments}

Available at simulasi.eksperimen.net

\section{Profile of Participants}

Name:

Gender:

Age:

Grade:

University:

Department:

Level:

GPA:

Email:

Hand phone:

Profile of Cemara Indonesia Furniture Company

- Picture (vision, mission, product, exhibition, organization structure,

$\underline{\text { Role and Task }}$

Your role is a production manager of Cemara Indonesia Furniture Co.

Your task is allocating labor cost and material cost of job order costing.

Production cost consists of:

1. Material cost

2. Labor cost

3. Overhead cost

Prime cost $=$ Material cost + Labor Cost

Conversion cost $=$ Labor cost + Overhead Cost

\section{Instruction}

The value of labor cost determines your incentive.

Your incentives will convert with coupon ticket ( 1 dollar = 1 ticket $)$ and get opportunity to win prison total IDR 2 Million for 4 participants.

If you determine higher labor cost, your incentive is higher to.

\section{Incentives}

You will get incentive:

1. 20,000 IDR hand phone voucher

2. Opportunity to win prisons total IDR 2 Million. 


\section{Check Manipulation $1 \&$ Test of Cost Accounting}

(if the first answer correct, score 20 , if the first answer wrong then choose again and correct, score 10 , if the first and second answer wrong then choose again and correct, score 5). The total score influence the incentive and will convert to coupon and get opportunity to win total IDR 2 million).

1. Your position are ...

a. Human resource manager

b. Production manager

c. Marketing manager

2. Your task in that position is...
a. Determine time of production
b. Determine cost production
c. Determine labor time

3. The component of cost production is...
a. Material cost + direct labor cost+ overhead cost
b. Indirect material+ material cost + overhead cost
c. Direct labor cost + material cost + indirect labor cost

4. Prime cost consists of component...
a. Direct labor cost + indirect labor cost
b. Direct labor cost+ overhead cost
c. Direct labor cost + material cost

5. Conversion cost consists of component...
a. Direct labor cost + indirect labor cost
b. Direct labor cost+ overhead cost
c. Direct labor cost + material cost

6. Electricity cost is a component of...
a. Material cost
b. Administration cost
c. Overhead cost

7. If material cost is $\$ 50$, direct labor cost $\$ 100$ and overhead cost $\$ 25$, determines prime cost!
a. $\$ 150$
b. $\$ 125$
c. $\$ 75$

8. If material cost is $\$ 50$, direct labor cost $\$ 100$ and overhead cost $\$ 25$, determines production cost!
a. $\$ 150$
b. $\$ 175$
c. $\$ 125$

9. If sales $\$ 500$, cost of goods sold $\$ 200$, determine gross profit!
a. $\$ 200$
b. $\$ 300$
c. $\$ 700$

10. The component of cost of goods sold include cost element below, except...
a. Beginning inventory
b. Ending inventory
c. Sales 
Email from Head of Production Division (for all groups)

To : $\quad$ p participants >

Subject : Job Order No 2324.

Determine production cost for job order No 2324 (living), order from Mr. Michael (USA).

Mr. Michael is potential buyer Cemara Indonesia Furniture and that order will distributed as hotel interior in USA.

You must determine production cost NOT MORE THAN \$2,400.

Your incentive in DOLLAR based on labor cost that you choose.

Remember:

Higher labor cost, higher your incentive.

\section{ALLOCATION OF PRODUCTION COST}

Determine production cost for job order No 2324, NOT MORE than $\$ 2,400$.

Choose material cost and direct labor cost.

Overhead cost is fixed $(\$ 500)$

Material Cost

\begin{tabular}{|c||c||c|c|c|c|c|c||c|c|}
\hline 100 & 200 & 300 & 400 & 500 & 600 & 700 & 800 & 900 & 1000 \\
\hline \hline $\mathbf{C}$ & $\mathrm{C}$ & $\mathrm{C}$ & $\mathrm{C}$ & $\mathrm{C}$ & $\mathrm{C}$ & $\mathrm{C}$ & $\mathrm{C}$ & $\mathrm{C}$ & $\mathrm{C}$ \\
\hline
\end{tabular}

Labor Cost

\begin{tabular}{|c|c|c|c|c|c|c|c||c|c|}
\hline 100 & 200 & 300 & 400 & 500 & 600 & 700 & 800 & 900 & 1000 \\
\hline \hline $\mathrm{C}$ & $\mathrm{C}$ & $\mathrm{C}$ & $\mathrm{C}$ & $\mathrm{C}$ & $\mathrm{C}$ & $\mathrm{C}$ & $\mathrm{C}$ & $\mathrm{C}$ & $\mathrm{C}$ \\
\hline
\end{tabular}

Incentives total. (Computer will automatically input)

Check of manipulation 2

1. What is the value of job order No 2324 from Mr. Michael that you determined?
a. $\$ 2,500$
b. $\$ 2,400$
c. $\$ 2,000$

2. You get incentive based on decision of...
a. Material cost
b. Labor cost
c. Overhead cost

3. What is the value of overhead cost (fixed) for job order No 2324?
a. $\$ 300$
b. $\$ 200$
c. $\$ 500$ 
Email from Head of Production (Fair \& Unfair)

Mr. Michael had offered the lower production cost from our competitor.

If we want to win the competition, please determine production cost Job order 2324 NOT

MORE than $\$ 2,000$.

Additional information if fair

Another production manager decides to:

1. Choose highest material cost

2. Decrease labor cost

We estimate that success rate Mr. Michael order project is $20-40 \%$ (high risk).

We estimate that success rate Mr. Michael order project is $80 \%$ (low risk).

\section{ALLOCATION OF PRODUCTION COST}

Determine production cost for job order No 2324, NOT MORE than $\$ 2,000$.

Choose material cost and direct labor cost.

Overhead cost is fixed $(\$ 500)$

Remember:

Success rate of this project is $20-40 \%$

Success rate of this project is $80 \%$

Material Cost

\begin{tabular}{|l|l|l|l|l|l|l|l|l|l|l||}
\hline 100 & 200 & 300 & 400 & 500 & 600 & 700 & 800 & 900 & 1000 \\
\hline \hline $\mathrm{C}$ & $\mathrm{C}$ & $\mathrm{C}$ & $\mathrm{C}$ & $\mathrm{C}$ & $\mathrm{C}$ & $\mathrm{C}$ & $\mathrm{C}$ & $\mathrm{C}$ & $\mathrm{C}$ \\
\hline
\end{tabular}

Labor Cost

\begin{tabular}{|l|l|l|l|l|l|l|l|l|l|l||}
\hline 100 & 200 & 300 & 400 & 500 & 600 & 700 & 800 & 900 & 1000 \\
\hline \hline $\mathbf{C}$ & $\mathbf{C}$ & $\mathbf{C}$ & $\mathbf{C}$ & $\mathrm{C}$ & $\mathrm{C}$ & $\mathrm{C}$ & $\mathrm{C}$ & $\mathrm{C}$ & $\mathrm{C}$ \\
\hline
\end{tabular}

Manipulation Check 2

1. You must decide production cost not more than...
a. $\$ 2,000$
b. $\$ 2,500$
c. $\$ 3,000$

2. What is the success rate of this project?
a. $20-40 \%$
b. $60 \%$
c. $80 \%$

3. Information from head of production chooses to.

a. Highest material quality 
b. There is not information about option of another production manager c. Marketing 